DOI: https://doi.org/10.24127/ajpm.v9i1.2543

\title{
PENGEMBANGAN MEDIA POP-UP BOOK BERBASIS CONTEXTUAL TEACHING AND LEARNING DALAM PENCAPAIAN KEMAMPUAN PEMECAHAN MASALAH
}

\author{
Dwi Oktaviana', Iwit Prihatin', Fahrizar ${ }^{3}$ \\ ${ }^{1,2,3}$ Pendidikan Matematika, IKIP PGRI Pontianak, Indonesia \\ E-mail: $\quad \frac{\text { dwi.oktaviana7@gmail.com }}{{ }^{1)}}$ \\ fahrizar23@gmail.com ${ }^{3)}$
}

Received 09 December 2019; Received in revised form 28 January 2020; Accepted 28 March 2020

\begin{abstract}
Abstrak
Penelitian ini bertujuan untuk menghasilkan media Pop-Up Book berbasis Contextual Teaching and Learning (CTL) dalam pencapaian kemampuan pemecahan masalah siswa SMP yang valid, praktis, dan efektif. Penelitian ini adalah penelitian pengembangan Thiagarajan dengan 3 tahap yaitu tahap define, design, dan develop. Produk valid dilihat dari hasil validasi ahli, produk praktis dilihat dari hasil angket, sedangkan produk efektif dilihat dari hasil uji coba. Hasil validasi para ahli memperoleh aspek materi dinyatakan valid dengan hasil sebesar $82,42 \%$, sedangkan aspek media dinyatakan sangat valid dengan hasil sebesar $86,15 \%$. Hasil angket respon guru memperoleh hasil sebesar $90,59 \%$, sedangkan hasil angket respon siswa diperoleh hasil sebesar $89,12 \%$ dengan kriteria sangat praktis. Hasil uji coba memperoleh hasil sebesar $81,58 \%$ dengan kriteria efektif dimana terdapat 31 siswa yang tuntas dan 7 siswa yang tidak tuntas dari standar kelulusan minimum yang ditentukan oleh sekolah adalah 75 untuk mata pelajaran matematika. Dengan demikian, dapat disimpulkan media Pop-Up Book berbasis CTL dapat menfasilitasi pencapaian kemampuan pemecahan masalah siswa SMP.
\end{abstract}

Kata kunci: CTL; kemampuan pemecahan masalah; pop-up book.

\begin{abstract}
This study aims to produce a Pop-Up Book media based on Contextual Teaching and Learning (CTL) in achieving valid, practical, and effective problem solving abilities of junior high school students. This research is a Thiagarajan development study with 3 stages: define, design, and develop. The validity of the product is seen from the results of expert validation, the practicality of the product is seen from the results of the questionnaire, while the effectiveness of the product is seen from the results of the trial run. The results of the validation of the experts obtained the material aspect was declared valid with $82.42 \%$, while the media aspect was declared very valid with $86.15 \%$. The results of the teacher questionnaire responses obtained of $90.59 \%$, while the results of student response questionnaires obtained of $89.12 \%$ with very practical criteria. The trial results obtained of $81.58 \%$ with effective criteria where there are 31 students who completed and 7 students who did not complete the minimum graduation standards determined by the school is 75 for mathematics. Therefore, it can be concluded that CTL-based Pop-Up Book media can facilitate the achievement of junior high school students' problem solving abilities.
\end{abstract}

Keywords: CTL; pop-up book; problem solving.

\section{PENDAHULUAN}

Seiring dengan berkembangnya ilmu pengetahuan dan pola berpikir siswa dalam pendidikan di Indonesia maka seorang guru juga harus memperhatikan kondisi tersebut. Seorang guru harus berusaha meningkatkan mutu pendidikan yaitu salah satunya dengan menggunakan media pembelajaran.

Fungsi utama media adalah memotivasi, menyajikan informasi dan memberi instruksi (Dewanti, Toenlloe, dan Soepriyanto, 2018). Beberapa 
penelitian yang mengungkapkan bahwa penggunaan media pembelajaran sangat penting diantaranya Suartama (2010) menyatakan penggunaan media dalam pembelajaran matematika mampu menjadikan proses pembelajaran lebih efektif dalam hal penyampaian materi, membantu siswa memahami materi, menyajikan informasi dengan menarik, mempermudah dalam penafsiran, serta memadatkan informasi; Wicaksono (2016) menyatakan peran media sangat penting dalam proses pembelajaran agar materi yang disampaikan oleh guru cepat sampai dan mudah diterima secara maksimal; dan Yusuf, Degeng, \& Adi (2018) menyatakan bahwa penggunaan media pembelajaran dapat mewujudkan situasi pembelajaran yang efektif, mempercepat proses pembelajaran, dan membantu siswa dalam upaya memahami materi yang disampaikan guru di dalam kelas. Oleh karena itu, media pembelajaran memiliki peran sangat penting dalam proses pembelajaran.

Penggunaan media dalam pembelajaran matematika harus dapat mengatasi keabstrakan dalam matematika. Salah satunya dengan menvisualisasikannya, Widodo \& Wahyudi (2018) mengungkapkan bahwa media pembelajaran dapat menvisualisakan materi matematika yang cenderung abstrak. Salah satu media pembelajaran yang dapat menvisualisasikan tersebut adalah media Pop-up book. Umayah dkk (2011) yang mengatakan bahwa media yang berbasis visualisasi yang berdimensi dapat menjadikan tampilan buku lebih menarik, sehingga pesan yang disampaikan mudah dipahami oleh pembaca. Okamura \& Igarashi (2010) menyatakan media Pop-Up adalah selembar kertas yang dilipat dimana struktur dua dimensi atau tiga dimensi muncul ketika dibuka.

Pop-Up Book sebagai media pembelajaran telah banyak dikembangkan diantaranya adalah Baiduri, Taufik, \& Elfiani (2019) mengembangkan media pembelajaran Pop-Up Book berbasis audio pada materi bangun datar segiempat di SMP, Marlina (2018) mengembangkan media Pop-Up Book materi soal cerita penjumlahan dan pengurangan kelas 1 SD, Mahayani dkk (2018) mengembangkan kotak Pop-Up berbasis Problem Solving pada materi cahaya dan alat-alat optik.

Pada penelitian sebelumnya telah dikaji tentang analisis kebutuhan terhadap media Pop-Up Book berbasis CTL terhadap kemampuan pemecahan masalah, hasil yang diperoleh yaitu siswa dan guru SMP Negeri 12 Pontianak membutuhkan media pembelajaran berupa Pop-Up Book untuk mengatasi keterbatasan bahan ajar yang dimiliki oleh sekolah. (Fahrizar dan Oktaviana, 2019). Oleh karena itu, penelitian ini melanjutkan penelitian sebelumnya dengan mengembangkan Pop-Up Book berbasis Contextual Teaching and Learning (CTL) terhadap kemampuan pemecahan masalah matematika siswa.

Beberapa pengembangan media Pop-Up Book sebelumnya belum mengembangkan berbasis CTL. Nugroho (2017) menyatakan bahwa CTL merupakan strategi pembelajaran yang membantu guru mengaitkan antara materi yang diajarkan dengan situasi dunia nyata siswa dan mendorong siswa membuat hubungan antara pengetahuan yang dimilikinya dengan penerapannya sehingga pembelajaran semakin bermakna. Selain itu, Sambada (2012) juga menyatakan di dalam CTL, siswa diajak untuk menikmati kegiatan 
belajarnya dengan memenuhi rasa keingintahuan mereka. Kondisi yang terjadi di SMPN 12 Pontianak juga memerlukan sebuah media yang menekankan pada pembelajaran CTL. Adapun berdasarkan penelitian sebelumnya diperoleh informasi bahwa siswa dan guru juga memerlukan metode pembelajaran yang dapat meningkatkan perhatian dan minat belajar siswa, membuat siswa membangun gagasannya sendiri, membuat siswa terlibat secara langsung, serta dekat dengan kehidupan seharihari agar siswa lebih mudah memahami konsep materi yang dipelajari serta bermakna. Untuk itu, pengembangan Pop-Up Book ini lebih menitikberatkan berbasis CTL.

Penelitian ini memfokuskan kepada peningkatan kemampuan pemecahan masalah dikarenakan pendekatan kontekstual sangat cocok untuk mengatasi kemampuan pemecahan masalah. Berdasarkan studi pendahuluan yang dilakukan ke SMPN 12 Pontianak diperoleh informasi siswa mengalami kesulitan dalam mengerjakan materi teorema phytagoras yang telah didapat kedalam bentuk soal cerita. Siswa masih belum terampil dalam memecahkan masalah dari soal dikarenakan siswa mengalami kesulitan dalam menerapkan materi yang diajarkan dengan pengetahuan yang telah didapat dan mengaplikasikannya kedalam kehidupan sehari-hari. Hal ini menunjukkan masih lemahnya kemampuan pemecahan masalah matematis siswa.

Beberapa penelitian yang relevan menggunakan CTL terhadap kemampuan pemecahan masalah diantaranya adalah Amir (2015) menyimpulkan bahwa ada pengaruh pembelajaran kontekstual terhadap kemampuan pemecahan masalah matematika siswa SD; Setiawan \& Harta (2014) menyatakan bahwa pendekatan kontekstual dalam pembelajaran matematika efektif pada aspek kemampuan pemecahan masalah matematis; Ayu, Maulana, \& Kurniadi (2016) menyatakan pendekatan kontekstual dapat meningkatkan kemampuan koneksi dan pemecahan masalah matematis siswa secara signifikan pada materi keliling dan luas persegi panjang dan segitiga; dan Isharyadi (2018) menyatakan bahwa peningkatan kemampuan pemecahan masalah matematis siswa yang mendapat pembelajaran dengan pendekatan kontekstual lebih baik daripada siswa yang mendapat pembelajaran dengan pendekatan saintifik. Berdasarkan penelitian yang relevan tersebut maka dapat diyakini bahwa media Pop-Up Book berbasis CTL ini dapat menfasilitasi pencapaian kemampuan pemecahan masalah siswa.

Adapun hubungan antar penelitian yang relevan dengan penelitian yang dilakukan adalah menghasilkan media Pop-Up Book berbasis CTL terhadap kemampuan pemecahan masalah pada materi teorema phytagoras. Sehingga tujuan dalam penelitian ini adalah menghasilkan media Pop-Up Book berbasis CTL terhadap kemampuan pemecahan masalah yang valid, praktis, dan efektif.

\section{METODE PENELITIAN}

Jenis penelitian ini adalah penelitian pengembangan (Research and Development). Penelitian dan pengembangan Pop-Up Book berbasis CTL ini menggunakan model pengembangan Thiagarajan yaitu 4-D yang terdiri dari Define, Design, Development and Dessemination. Pada penelitian ini hanya melakukan sampai pada tahap development. 
Pada tahap pendefinisian (define) merupakan kegiatan analisis kebutuhan yang dilakukan melalui penelitian. Kegiatan analisis yang dilakukan meliputi analisis awal dan identifikasi kebutuhan. Kegiatan analisis awal bertujuan untuk melakukan observasi awal tentang hal-hal yang berkaitan dengan pengembangan pop-up book berbasis CTL. Kegiatan identifikasi kebutuhan bertujuan untuk mempelajari kebutuhan siswa serta mengidentifikasi tujuan pembelajaran dalam pengembangan Pop-Up book berbasis CTL.

Pada tahap perancangan (design) ini dirancang media Pop-Up book berbasis CTL yang disesuaikan dengan tahap define. Kemudian dilanjutkan dengan membuat media Pop-Up book berbasis CTL. Tahap pengembangan (development) ini memperbaiki media Pop-Up book berbasis CTL berdasarkan validasi para ahli dan melakukan uji coba produk. Uji coba dilakukan di SMP Negeri 12 Pontianak dengan subjek siswa kelas VIII sebanyak 38 orang. Bagan aktivitas pengembangan dalam penelitian ini disajikan pada Gambar 1.

Pop-Up book berbasis CTL yang dikembangkan melalui studi pendahuluan diuji validitasnya oleh dosen IKIP PGRI Pontianak sebanyak 3 orang sebagai ahli media dan ahli materi pembelajaran. Data validasi terdiri atas data kuantitatif. Data kuantitatif merupakan skor-skor yang diperoleh dari validator, angket kepraktisan dan keefektifan dengan menggunakan skala. Sementara, data kualitatif berupa saran, komentar, dan kritik baik secara tertulis maupun lisan. Data validasi baik kuantitatif dan kualitatif digunakan sebagai bahan pertimbangan untuk melakukan revisi demi penyempurnaan media Pop-Up book berbasis CTL.

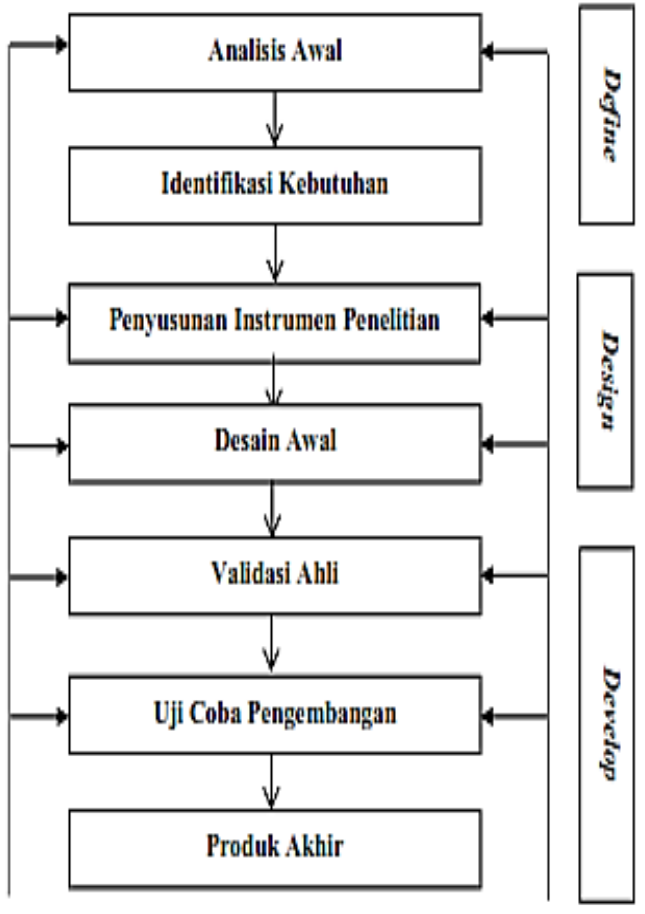

Gambar 1. Tahap-tahap pengembangan pop-up book berbasis CTL.

Instrumen yang digunakan dalam penelitian ini adalah (1) lembar validasi ahli; (2) angket respon siswa dan guru; dan (3) soal tes yang mengukur kemampuan pemecahan masalah siswa. Ketiga instrumen tersebut digunakan untuk mengetahui kevalidan, kepraktisan, dan keefektifan dari media Pop-Up book berbasis CTL ini.

Uji kevalidan menggunakan lembar validasi, sedangkan data yang diamati adalah kevalidan media $P o p-U p$ book berbasis CTL, soal tes kemampuan pemecahan masalah, dan angket siswa dan guru yang diisi oleh 3 orang pakar atau para ahli terhadap materi, media, dan bahasa yang digunakan. Uji kepraktisan menggunakan angket, data diisi oleh 38 orang siswa SMP Negeri 12 Pontianak. Uji kefektifan menggunakan soal tes kemampuan pemecahan masalah setelah diajarkan menggunakan media Pop-Up book berbasis CTL. Soal tes kemampuan pemecahan masalah yang 
diberikan berbentuk essai sebanyak 4 buah dengan memuat indikator memahami masalah, membuat rencana penyelesaian, melaksanakan penyelesaian, dan memeriksa kembali.

Hasil kevalidan, kepraktisan, dan keefektifan media Pop-Up book berbasis CTL disajikan pada Tabel 1.

Tabel 1. Tingkat kevalidan, kepraktisan, dan keefektifan produk.

\begin{tabular}{|c|c|c|}
\hline $\begin{array}{c}\text { Penilaian } \\
\text { (Kevalidan, } \\
\text { Kepraktisan, } \\
\text { Keefektifan) }\end{array}$ & $\begin{array}{r}\text { Skala } \\
\text { Nilai }\end{array}$ & $\begin{array}{c}\text { Hasil Rating } \\
\text { Persentase (\%) }\end{array}$ \\
\hline $\begin{array}{c}\text { Sangat } \\
\text { Valid/Praktis/ } \\
\text { Efektif }\end{array}$ & 5 & $85<$ rata-rata $\leq 100$ \\
\hline $\begin{array}{c}\text { Valid/Praktis/ } \\
\text { Efektif } \\
\text { Cukup }\end{array}$ & 4 & $65<$ rata-rata $\leq 85$ \\
\hline $\begin{array}{c}\text { Valid/Praktis/ } \\
\text { Efektif } \\
\text { Tidak }\end{array}$ & 3 & $50<$ rata-rata $\leq 65$ \\
\hline $\begin{array}{l}\text { Valid/Praktis/ } \\
\text { Efektif } \\
\text { Sangat Tidak }\end{array}$ & 2 & $35<$ rata-rata $\leq 50$ \\
\hline $\begin{array}{c}\text { Valid/Praktis/ } \\
\text { Efektif }\end{array}$ & 1 & $20<$ rata-rata $\leq 35$ \\
\hline
\end{tabular}

Produk ini valid jika persentase rata-rata nilai validator $>65 \%$, produk praktis jika persentase rata-rata respon siswa dan guru $>65 \%$, dan produk efektif jika persentase rata-rata nilai tes siswa yang mencapai KKM > 65\%. Adapun KKM yang telah ditentukan oleh pihak sekolah adalah 75 .

\section{HASIL DAN PEMBAHASAN}

Deskripsi pengembangan media Pop-Up book berbasis CTL materi teorema phytagoras untuk siswa SMP dari tahap define sampai tahan development dijabarkan sebagai berikut.

\section{Define (Pendefinisian)}

Pada tahap define ini kegiatan yang dilakukan adalah menganalisis masalah yang ada di sekolah berkaitan dengan pembelajaran matematika di kelas. Selanjutnya dilakukan observasi dan wawancara terhadap guru bidang studi matematika dan siswa SMP Negeri 12 Pontianak.

Berdasarkan observasi dan wawancara dengan salah satu guru bidang studi matematika, untuk bahan ajar yang digunakan di sekolah hanya menggunakan buku paket saja. Informasi lain diperoleh bahwa adanya keterbatasan penggunaan media pembelajaran di sekolah. Guru dalam mengajar hanya mengandalkan buku paket saja tanpa membuat media pembelajaran sendiri yang dapat membangun keaktifan siswa dalam pembelajaran. Buku paket yang digunakan sudah sesuai dengan kurikulum 2013 dan memenuhi KI, KD serta indikator pencapaiannya. Namun, buku paket hanya menampilkan unsur dua dimensi yang berupa gambar ilustrasi saja sedangkan untuk materi teorema phytagoras diperlukan ilustrasi nyata dalam mengamati objek yang disajikan sehingga diperlukan media pembelajaran yang dapat menampilkan objek tersebut secara nyata dengan memiliki unsur tiga dimensi.

Lebih lanjut, guru mengungkapkan bahwa masih menggunakan metode pembelajaran konvensional dalam pembelajaran. Metode pembelajaran konvensional kurang membantu siswa dalam pemahaman konsep teorema phytagoras karena tidak adanya pendekatan secara nyata terhadap objek yang dipelajari dan masih jauh dengan kehidupan sehari-hari.

Selanjutnya dilakukan observasi dan wawancara kepada siswa. Analisis siswa dilakukan untuk mengetahui data siswa yang meliputi karakter siswa dan kebutuhan siswa. Berdasarkan observasi yang dilakukan di salah satu kelas VIII 
dengan jumlah siswa sebanyak 38 orang, karakter siswa kelas VIII SMP Negeri 12 Pontianak yaitu siswa kurang berminat belajar mata pelajaran matematika dikarenakan siswa kurang memperhatikan pembelajaran pada saat guru menjelaskan pembelajaran dimana siswa sibuk dengan aktivitasnya sendiri. Siswa yang mendengarkan penjelasan guru pada saat mengajar juga kurang aktif dalam proses pembelajaran. Kegiatan dalam pembelajaran juga banyak didominasi oleh guru dikarenakan kurang aktifnya siswa dalam pembelajaran. Berdasarkan karakter yang ditemukan maka perlu menggunakan pendekatan yang mampu mendorong siswa untuk aktif, siswa yang mendominasi dalam pembelajaran dibandingkan guru, siswa dapat bereksplorasi, dan siswa dapat menemukan gagasannya sendiri.

Analisis kebutuhan siswa dilakukan untuk mengetahui masalah yang dihadapi siswa dalam proses pembelajaran. Berdasarkan wawancara yang dilakukan dengan beberapa siswa kelas VIII SMP Negeri 12 Pontianak diperoleh informasi siswa merasa bosan dikarenakan bahan ajar yang digunakan monoton hanya berisi materi, contoh soal dan soal latihan. Selain itu, di dalam buku paket yang digunakan kurang menarik, tidak ada unsur gambar, dan kurang berwarna sehingga minat siswa untuk membaca buku paket tersebut kurang. Dilihat dari pemahaman materi diperoleh informasi siswa kesulitan dalam menyelesaikan soal cerita yang berhubungan dengan materi teorema phytagoras. Siswa sulit membayangkan atau mengilustrasikan objek yang diberikan pada soal. Oleh karena itu, siswa membutuhkan media pembelajaran yang dapat menyajikan objek secara nyata untuk mempelajari matematika yang tersifat abstrak dan didukung dengan pendekatan yang nyata juga. Siswa juga membutuhkan media pembelajaran yang menarik dan menyenangkan (Fahrizar dan Oktaviana, 2019).

Pada pengembangan media PopUp Book ini mengkombinasikan dengan aspek-aspek pada pendekatan CTL sehingga membuat siswa tidak bosan ketika menggunakan media ini. Selain itu, Pop-up book menyajikan gambar dalam bentuk tiga dimensi untuk memudahkan siswa dalam membayangkan objek yang disajikan dalam soal teorema phytagoras sehingga siswa diharapkan akan lebih mudah memahami konsep teorema phytagoras dan memahami soal-soal untuk menyelesaikannya.

\section{Design (Perancangan)}

Pada tahap design ini kegiatan yang dilakukan adalah membuat instrumen penelitian yang diperlukan untuk penelitian meliputi: (1) lembar validasi untuk para ahli; (2) angket untuk siswa dan guru; dan (3) soal yang memuat kemampuan pemecahan masalah.

Selanjutnya, mendesain media pop-up book berbasis CTL sedemikian rupa sehingga berbeda dengan buku paket yang digunakan untuk tingkat SMP. Media Pop-Up book berbasis CTL berisi (a) sampul atau cover popup book terdiri dari judul buku, judul materi, kotak identitas siswa, dan nama penulis; (b) halaman pembuka berisikan kata pengantar yang mengingatkan siswa bahwa pythagoras banyak digunakan dalam kehidupan sehari-hari, kompetensi dasar dan tujuan pembelajaran; (c) materi dan soal popup book berbasis CTL dibuat dengan mengorientasi siswa pada masalah. Masalah-masalah yang disajikan berupa masalah yang berkaitan dalam 
kehidupan sehari-hari. Hal tersebut bertujuan untuk melatih kemampuan pemecahan masalah matematis siswa. Di dalam pop-up book ini juga terdapat soal latihan yang berisikan masalah sehari-hari berdasarkan sub bahasan yang telah dipelajari. Penyajian materi dan soal diselipkan gambar dengan unsur tiga dimensi agar siswa tidak bosan, media menjadi menarik, dan siswa dalam mengamati secara langsung ilustrasi gambar yang tersajikan pada soal; dan (4) rangkuman berisi garis besar materi yang telah dipelajari. Rangkuman bertujuan mengingatkan kembali materi yang telah dipelajari dan dianggap penting.

\section{Development (Pengembangan)}

Pada tahap development ini kegiatan yang dilakukan adalah melakukan validasi media pop-up book berbasis CTL, angket siswa dan guru serta soal kemampuan pemecahan masalah siswa.

Tabel 4. Hasil penilaian ahli terhadap kevalidan media.

\begin{tabular}{ccc}
\hline \multirow{2}{*}{ Validator } & \multicolumn{2}{c}{ Penilaian (\%) } \\
\cline { 2 - 3 } & Ahli Materi & Ahli Media \\
\hline Validator I & 83,03 & 86,15 \\
Validator II & 81,82 & 87,69 \\
Validator III & 82,42 & 84,62 \\
Skor Rata-rata & 82,42 & 86,15 \\
\hline
\end{tabular}

Proses validasi dilakukan oleh 3 orang validator untuk mengetahui kevalidan pop-up book berbasis CTL yang dikembangkan. Aspek didalam pop-up book yang dinilai oleh ketiga validator adalah aspek materi dan aspek media. Sub aspek dalam materi meliputi kelayakan isi, penyajian, bahasa, dan penilaian model Contextual Teaching and Learning (CTL). Sedangkan sub aspek dalam media meliputi ukuran pop-up book, desain sampul pop-up book, dan desain isi pop-up book. Media Pop-Up book berbasis CTL dikatakan valid jika skor rata-rata penilaian $>65 \%$. Rincian skor penilaian ahli disajikan dalam Tabel 4.

Dari hasil penilaian ketiga ahli tersebut diperoleh hasil bahwa media Pop-Up book berbasis CTL yang dikembangkan memenuhi kriteria kevalidan dengan beberapa saran dari ahli materi dan ahli media untuk perbaikan media Pop-Up book berbasis CTL sebelum diujicobakan ke siswa SMP. Hasil validasi dari ahli media dan matei memperoleh persentase rata-rata sebesar 84,28\% dengan kriteria valid yang artinya media pop-up book berbasis CTL layak digunakan sebagai media pembelajaran pada materi teorema phytagoras. Media ini dikatakan sangat praktis karena respon siswa dan guru sangat baik. Media ini juga dikatakan efektif dalam pencapaian kemampuan pemecahan masalah siswa yang diukur dengan persentase ketuntasan klasikal sebesar 81,58\%. Media ini dapat dijadikan alternatif oleh guru dalam pembelajaran materi teorema phytagoras.

Adapun saran dari ahli materi dan ahli media antara lain adalah: (1) isi dari kata pengantar dibuat sebagai pendahuluan materi. Bahwa kata pengantar sebelum revisi hanya berisi kalimat motivasi pada siswa sedangkan setelah revisi, kata pengantar menjadi lebih mengarahkan ke siswa apa yang akan dipelajari pada materi teorema pythagoras.

Selanjutanya, saran terkait (2) gambar pada halaman pertama seharusnya berhubungan dengan materi yang disampaikan. Gambar pada halaman pembuka sebelum direvisi itu dinosaurus, yang tidak ada kaitannya dengan matematika. Sedangkan setelah direvisi, gambar pada halaman pembuka 
menjadi bangun ruang yaitu limas yang sisi-sisinya adalah segitiga. Hasil revisi yang dilakukan dapat dilihat pada Gambar 2.

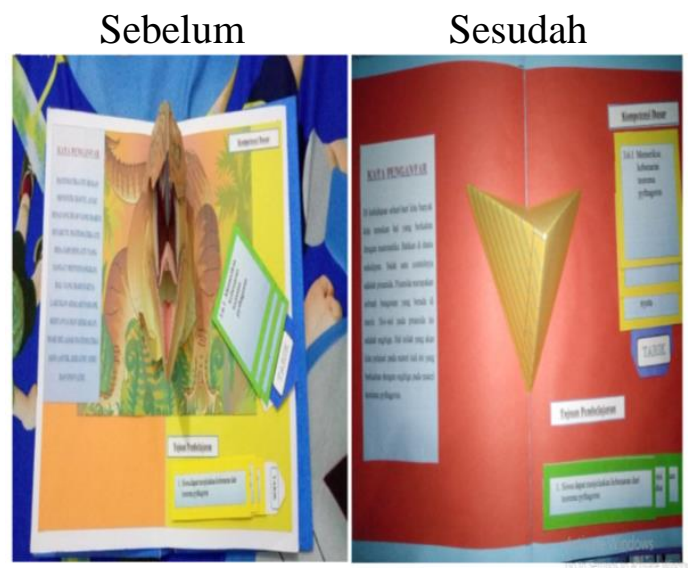

Gambar 2. Perbaikan Konteks Gambar.

Para ahli juga memberikan saran (3) soal-soal latihan pada media tersebut harusnya dibuat kontekstual. Terakhir para ahli memberi saran terkait (4) lebih memaksimalkan visualisasi gambar daripada hanya sekedar tulisan. Sebelum direvisi soal-soal hanya berupa tulisan yang ditempel pada media sedangkan setelah direvisi, soal-soal yang diberikan dibuat dengan visualisasi gambar sehingga lebih menarik seperti pada Gambar 3.

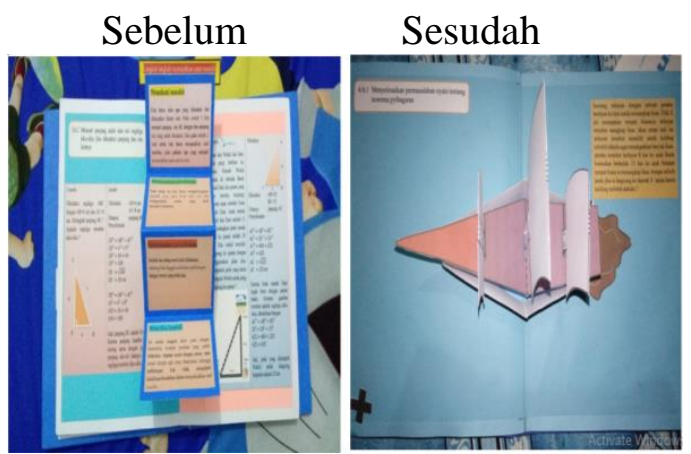

Gambar 3. Perbaikan Visualisasi Gambar

Hasil revisi dari para ahli tersebut selanjutnya dilakukan uji coba terbatas pada siswa SMP Negeri 12 Pontianak.
Uji coba ini bertujuan untuk melihat kepraktisan dan keefektifan рор-ир book berbasis CTL sebagai media pembelajaran yang dikembangkan dalam materi teorema phytagoras. Kepraktisan dalam uji coba terbatas dilihat dari hasil angket respon guru dan siswa. Hasil angket tersebut digunakan untuk merevisi pop-up book berbasis CTL menjadi produk akhir. Hasil angket repon guru dan siswa terhadap pop-up book berbasis CTL disajikan pada Tabel 5.

Tabel 5. Hasil angket respon guru dan siswa

\begin{tabular}{ccc}
\hline Responden & $\begin{array}{c}\text { Hasil Rating } \\
(\boldsymbol{\%})\end{array}$ & Kriteria \\
\hline Guru & 90,59 & $\begin{array}{c}\text { Sangat } \\
\text { Praktis }\end{array}$ \\
Siswa & 89,12 & $\begin{array}{c}\text { Sangat } \\
\text { Praktis }\end{array}$ \\
\hline
\end{tabular}

Dari angket yang diberikan kepada siswa dan guru tidak terdapat revisi terhadap media pop-up book berbasis CTL. Sedangkan keefektifan pop-up book berbasis CTL dilihat dari hasil tes kemampuan pemecahan masalah. Dari tes yang diberikan kepada siswa SMP Negeri 12 Pontianak memperoleh hasil sebanyak 31 siswa yang tuntas dan 7 orang siswa yang tidak tuntas dikarenakan belum memenuhi KKM sehingga persentasenya adalah $81,58 \%$ dengan kriteria efektif.

Dari hasil uji coba media Pop-Up book berbasis CTL ini temuan yang menarik antara lain yaitu (1) selama pembelajaran siswa sangat berinteraksi dengan guru dan siswa yang lain, aktivitas siswa dalam pembelajaran sangat bersemangat karena media PopUp book berbasis CTL menuntut siswa untuk aktif dalam pembelajaran. Hal ini sejalan dengan penelitian Bernadi (2017) mengungkapkan bahwa rata-rata 
aktivitas siswa selama mengikuti pembelajaran dengan berbantuan media Pop-up book sangat tinggi dan media Pop-up book efektif digunakan dalam pembelajaran. Selain itu ditemukan (2) Media Pop-Up book membuat siswa dapat dengan mudah memahami maeri dan menemukan hasil jawaban soal yang diberikan karena disajikan gambar yang berbentuk visualisasi. Hal ini sejalan dengan penelitian Nurhayati \& Afifah (2017) mengungkapkan bahwa selain menjadi sebuah media edukatif bagi siswa SMA, buku Pop-up dapat juga dijadikan sebagai sumber belajar yang menarik, kreatif, dan inovatif. Siswa juga dapat memahami dan mempelajari materi dengan mudah dan tidak membosankan. Selanjutnya ditemukan (3) dalam uji coba media Pop-up book berbasis CTL, pembelajaran menggunakan pembelajaran kelompok dimana siswa saling membantu satu sama lain dalam mengerjakan soal pada media tersebut. Kerjasama dan diskusi dalam kelompok terlihat pada saat uji coba. Siswa dalam satu kelompok saling bertukar pikiran dalam menyelesaikan soal yang memuat kemampuan pemecahan masalah. Wismath \& Orr (2015) mengungkapkan bahwa dengan berdiskusi siswa mampu menemukan jalan lain dalam memecahkan masalah.

Media Pop-up book ini mengusung pendekatan CTL dalam penyusunannya, yang mana dalam media Pop-up book ini siswa disajikan permasalahan dimana siswa dapat mengkonstruk pemahamannya sendiri. Selain itu, disajikan juga bagian dimana siswa diminta menemukan konsep dari teorema phytagoras agar tertanam dalam ingatan siswa. Siswa juga dibentuk dalam kelompok agar siswa dapat saling membantu dan bertukar pikiran satu dengan yang lainnya.
Sehingga guru tidak perlu terlalu monoton dalam pembelajaran dimana peran aktif siswa sangat diperlukan dalam pembelajaran dan membangun pengetahuannya.

Pada saat pembelajaran dengan media pop-up book berbasis CTL siswa diberikan soal yang memuat soal cerita yang mengarah kepada kemampuan pemecahan masalah terhadap materi teorema phytagoras. Pembelajaran CTL yang menekankan kepada menemukan konsep sehingga membuat siswa dapat dengan mudah mengetahui konsep yang digunakan dalam menyelesaikan soal kemampuan pemecahan masalah tersebut. Selain itu, dengan adanya bentuk gambar visualisasi yang tersajikan pada pop-up book membuat siswa lebih mudah dalam menyelesaikan soal tersebut. Sehingga ketika siswa melakukan uji coba terbatas memperoleh hasil dengan kriteria efektif dikarenakan pada saat proses pembelajaran dengan menggunakan media pop-up book berbasis CTL ini siswa telah terbiasa dihadapkan dengan soal kemampuan pemecahan masalah dan telah dapat melakukan visualisasi dengan adanya disajikan secara nyata.

\section{KESIMPULAN DAN SARAN}

Berdasarkan hasil penelitian dan pembahasan maka dapat disimpulkan bahwa pengembangan media Pop-Up book berbasis CTL dalam pencapaian kemampuan pemecahan masalah siswa SMP adalah valid, sangat praktis, dan efektif. Adapun saran yang dapat diberikan berdasarkan hasil penelitian ini adalah untuk penelitian selanjutnya diharapkan dapat mengembangkan media pembelajaran Pop-up book dimana memuat model pembelajaran selain CTL atau pada materi lain. 


\section{DAFTAR PUSTAKA}

Amir, M. F. (2015). Pengaruh Pembelajaran Kontekstual Terhadap Kemampuan Pemecahan Masalah Matematika Siswa Sekolah Dasar. Prosiding Seminar Nasional Pendidikan: "Peningkatan Kualitas Peserta Didik Melalui Implementasi Pembelajaran Abad 21", 34-42. Fakultas Keguruan dan Ilmu Pendidikan Universitas Muhammadiyah Sidoarjo

Ayu, A. R., Maulana, \& Kurniadi, Y. (2016). Pengaruh Pendekatan Kontekstual Terhadap Kemampuan Koneksi dan Pemecahan Masalah Matematis Siswa Sekolah Dasar Pada Materi Keliling dan Luas Persegi Panjang dan Segitiga. Jurnal Pena Ilmiah, 1(1), 221-230.

Baiduri, Taufik, M., \& Elfiani, L. (2019). Pengembangan Media Pembelajaran Pop-Up Book Berbasis Audio Pada Materi Bangun Datar Segiempat di SMP. AKSIOMA: Jurnal Program Studi Pendidikan Matematika, 8(1), 248-261.

Bernadi, A. I. (2017). Pendidikan Kesiapsiagaan Bencana Tanah Longsor untuk Siswa Anak Usia Dini dengan Metode Dongeng Berbasis Media Pop Up Book di Paud Dewi Sartika Kecamatan Bergas. Jurnal Pendidikan Geografi, 23(2), 85-93.

Fahrizar \& Oktaviana, D. (2019). Analisis Kebutuhan dan Kelayakan Media Pembelajaran Pop-Up Book Berbasis Contextual Teaching and Learning. Prosiding Seminar Nasional Pendidikan: "Peningkatan Mutu Pendidikan MIPA dan Teknologi di Era Revolusi Industri 4.0”, 313-320.
Fakultas Pendidikan MIPA dan Teknologi IKIP PGRI Pontianak. Isharyadi, R. (2018). Pengaruh Penerapan Pendekatan Kontekstual Terhadap Peningkatan Kemampuan Pemecahan Masalah Matematis Siswa. AKSIOMA: Jurnal Pendidikan Matematika, 7(1), 4855.

Mahayani, S., dkk. (2018). Kotak Popup Berbasis Problem Solving: Pengembangan Media Pembelajaran pada Materi Cahaya dan Alat-Alat Optik untuk Kelas VIII SMP. Jurnal Pendidikan Matematika dan IPA. 9(2), 98108.

Marlina, M. (2018). Pengembangan Media Pop-Up Book Materi Soal Cerita Penjumlahan dan Pengurangan Kelas 1 SD. Jurnal Pendidikan Guru Sekolah Dasar, 37(7), 3635-3648.

Nugroho, A. G. (2017). Eksperimentasi Strategi Pembelajaran Matematika Berbasis Masalah (Problem Solving) dan Kontekstual (Contextual Teaching and Learning) Ditinjau Dari Gaya Belajar Siswa Di SMPN 1 Martapura. Jurnal Pendidikan Matematika, 2(2), 59-82.

Nurhayati, R. \& Afifah, L. (2017). Pengembangan Media Pembelajaran Buku Pop-Up untuk Pembelajaran Karya Sastra Bahasa Jerman di Kelas XI SMA Negeri 1 Tarik Sidoarjo. Journal Deutsch als Fremdsprache in Indonesian, 1(2), 1-8.

Okamura, S. \& Igarashi, T. (2010). An Assistant Interface to Design and Produce a Pop-Up Card. International Journal of Creative Interfaces and Computer, 1(2), 40-50. 
Sambada, D. (2012). Peranan Kreativitas Siswa Terhadap Kemampuan Pemecahan Masalah Fisika dalam Pembelajaran Kontekstual. Jurnal Penelitian Fisika dan Aplikasinya (JPFA), 2(2), 37-47.

Setiawan, R. H., \& Harta, I. (2014). Pengaruh Pendekatan Open-Ended dan Pendekatan Kontekstual Terhadap Kemampuan Pemecahan Masalah dan Sikap Siswa Terhadap Matematika. Jurnal Riset Pendidikan Matematika, 1(2), 240-256.

Suartama, I. K. (2010). Pengembangan multimedia untuk meningkatkan kualitas pembelajaran pada mata kuliah media pembelajaran. Jurnal Pendidikan dan Pengajaran, 43(3), 253-262.

Umayah, dkk. (2011). Pengembangan Modul Pop-Up Untuk Pembelajaran IPA Model Kooperatif dan Metode Diskusi. UNNES Science Education Journal, 2(2), 1-6.

Wicaksono, S. (2016). The Development of Interactive Multimedia Based Learning Using Macromedia Flash In Accounring Course. Journal of Accounting and Business Education, 1(1), 122-139.

Widodo, S. A., \& Wahyudi. (2018). Selection of Learning Media Mathematics for Junior Scholl Students. TOJET (The Turkish Online Journal of Educational Technology), 17(1), 154-160.

Wismath, S. L., \& Orr, D. (2015). Collaborative Learning in Problem Solving: A Case Study in Metacognitive Learning. The Canada Journal for the Scholarship of Teaching and Learning, 6(3), 1-11.
Yusuf, W. L., Degeng, I. N. S., \& Adi, E. P. (2018). Pengembangan Multimedia Interaktif Pelajaran Baca Tulis Aksara Jawa dengan Sandhangan. Jurnal Inovasi dan Teknologi Pembelajaran, 4(2), 9498. 